\title{
APPLICATION OF GEOGRAPHIC INFORMATION SYSTEMS IN THE
} GEOGRAPHICAL RESEARCH

\author{
Krishna Poudel, PhD \\ Dapartment of Geography Education \\ kpoudel_pokhara@yahoo.co.uk
}

\begin{abstract}
Geographical research is a search to get answers of questions or queries concerning about the phenomena of space, society, humanity and natural processes. Geographical Information Systems (GIS) help to carry on the study through enabling the data capture, database management, information handling and analyzing the complex phenomena within an interactive user's interface environment with high degree of accuracy and in a short time. Verticality and variations are the properties of mountains landscape. Application of GIS on geographical research enables to analyze those specific properties of mountain landscape with attainable accuracy level. This paper is an attempt to bring the applicability of GIS in the geographical research in the mountain context based on the available secondary information of various sources. Research queries in geographical subject, introduction of GIS and its development in Nepal, research issues, application of GIS and challenges and the new strategy for the application of GIS in the mountain context are explained in detail.
\end{abstract}

Key words: Geographical research, geographical information systems, mountain landscape, digital database, national spatial data infrastructure,

\section{GEOGRAPHICAL RESEARCH}

The term 'research' as defined in Webster's New Collegiate Dictionary is 'to search or investigate thoroughly or studious inquiry or examination or experimentation aimed at the discovery and interpretation of facts, revision of accepted theories or laws in the light of new facts, or practical application of such new or revised theories or laws'. Howard and Sharp (1983) defines research as "seeking through methodical processes to add to one's own body of knowledge and, hopefully, to that of others, by the discovery of non-trivial facts and insights" (Bell 1999:2). Bell (1999:2) also quotes Drew (1980) that research is conducted to solve problems and to expand knowledge as well as it is a systematic way of asking questions, a systematic method of enquiry with the systematic approach.

Most often the geographical research intends to search answer of certain questions originating from the interrogative terms like: what, where, when, how, and why.

WHAT often concerns with the geographical object. The earth has different geographical objects and the investigation prefers to identify those objects clearly. In computer based GIS environment geographic objects handles in two different ways i.e. Cartesian system (which is displayed into $x, y$ coordinate system) and the cell or grid of row and column. In the Cartesian system geographical objects are generalized into the geometric shape and size or their nature of distribution. Those can be interpolated into two dimensional coordinate geometric shapes. All the features of the earth surface could be generalized only into three types i.e. point, line and area feature. However, the case of point and line can be subjective with the scale factor. Suppose a house can be a point. If further zoom in to large scale drawing those may have plane. In the same way a river or road can be depicted by a line in a small scale but they may have sufficient breadth in large scale representation. Therefore, the representation of a geographic object, in terms of WHAT, might be a subject of generalization of representation. In the cell representation system, all the geographical objects of the earth surface are presented in the row and column system. The shape, size and boundary of an object is highly generalized and based on the cell size. Often the continuous data like surface and large homogeneous features representation in GIS environment use grid or cell system.

WHERE is related with the space or place. The place of the earth is referred in terms of location. There are two basic reference systems i.e. relative location and absolute location. The relative location system is basically explained in relation to another object. The relative reference of the object could have a variable nature and may not be fixed universally. Absolute location of the objects on the earth surface is used to refer with the help of universally adopted latitude and longitude value of particular location. Whole earth is divided into different latitude and longitude line with reference to Equator, Pole, Central Meridian and Prime Meridian lines. The lines of latitude start from the equator and ends at the pole. The equator is marked with $0^{\circ}$ and the Pole is with $90^{\circ}$. Similarly, the lines of langitude are drawn with marking $0^{\circ}$ at the Greenwich or 
Central Meridian and $180^{\circ}$ at Prime Meridian. Based on these absolute lines, each and every location of the earth surface could be marked with exact location. In the computer-based GIS environment 'georeference' is a common terminology followed to reference the object for the further analysis.

WHEN refers to the time dimension of certain events or activities or the position of the geographical facts. Most of the geographical facts are dynamic in nature. In geographical queries the time dimension is important to mark the dynamism of the objects. The famous 'Uniformity' doctrine of the study of origin of the earth surface morphology describes the 'the present is the key to the past' placed the time dimension in the center of geographical study. Change detection and monitoring activities are closely linked with the time factor. Therefore, WHEN is always marked its important role on geographical research. In the computer-based GIS environment database are often time referenced which enables to answer the questions concern with the changes.

HOW is basically associated with the process. Geography is a scientific discipline and always concerns with query of the process of changes or the dynamism of the geographical objects. The change takes place with certain process and patterns specific to change and with certain time dimension. Based on these reasons the role of HOW is important in the geographical queries. In computer-based GIS, environment ' $\mathrm{HOW}$ ' usually derives from the geographical features overlay or superimposing in a single view window or a uniform single map extension.

WHY a statement is finally marked with the changes which have been taken place and in the mean time 'what if' the changes have taken place. The question of WHY often follows a highly advanced level of search. Most of the investigation requires complicated test and methodologies to get the answer of WHY. In the computer-based GIS environment 'what if' is usually carried by simulating the geographical objects and the variables by spatial overlay, temporal overlay, attribute overlay and mathematical or arithmetical and logical operations.

The other terms of the interrogative i.e. ' $\mathrm{WHO}^{\prime}$ and 'WHOM' are generally covered by answering the queries of the process of change and the pattern of change by analyzing the variables of geographical objects and the attribute information.

\section{GEOGRAPHICAL INFORMATION SYSTEMS}

Geographical Information Systems (GIS) were devised in the 1960s as computer applications for handling volumes of information obtained from maps as well as for performing operations that would otherwise be too tedious, expensive, or inaccurate to perform by hand (Aronoff 1989; Peuquet and Marble 1990:50). Recent trends have been towards the development of GI Science and Technology (Goodchild 2004:710). GIS, Remote Sensing (RS) and Global Positioning Systems (GPS) are jointly operating in a single sphere of GI science and technology also called '3-S' systems (Deichmann and Wood 2005).

The last decade witnessed an unprecedented growth and development in earth observation data and applications. Earth observation techniques through remote sensing are proving to be more cost effective than ground-based techniques over large areas. RS data have the benefits of the synoptic view of a large area, which helps in obtaining the proverbial 'bird's eye-view' of the features, especially of inaccessible mountainous terrain. Furthermore, there has been an emergence of high-resolution satellite data in recent years, with greater degree of spatial and temporal variations than ever before. Similarly, GPS technology provides the ability to compute and capture position anywhere on the earth's surface with 24-hour coverage. Systems like Google Earth and Microsoft Virtual World have revolutionized the way we access and visualize satellite-based information seamlessly from local to global levels with unprecedented level of details.

Advances in information and communication technology combined with earth observation technology and geographical analysis and modeling tools are now available to quantify, model, document, and disseminate information on key socioeconomic, environmental, and natural resources conditions and trends. This convergence of information technology (computers, databases, software, networks, especially the Internet), and space science technology (remote sensing, global positioning system, light detection and ranging (LiDAR) have provided effective and promising tools and methods for dealing with diverse mountain issues. Geo-Information (GI) Systems have emerged as powerful tools in integrating and analyzing information from divergent sources and presenting the results in an effective and efficient way. These factors have led to the creation of a suitable context for institutional and technological 
framework for the use and access of geographic information for improved decision-making.

\section{GEOGRAPHICAL INFORMATION SYSTEMS IN NEPAL}

Different formal or informal academic gatherings of the recent days in Kathmandu people of various academic backgrounds used to talk about geographic information systems, its application and use. Many of those interpretations and observations have been based on the basis of applications of the discipline so far made in the local context. In Nepal, the application of space technology in the form of remote sensing was introduced in the later part of 1970s. The successful LANDSAT mission of NASA and the new development of earth observation satellite technology in 1970s have encouraged the donor communities to establish the mapping technology even in developing countries. Remote sensing data analysis laboratory was established in Kathmandu in 1979 from the support of USAID with the capability of Landsat MSS data processing, mapping and monitoring the regional land cover information within the government framework.

Given the policy significance accorded to forestry resources during the 1970's, remote sensing technologies in Nepal were heavily employed in mapping forest coverage. This Center tried somehow to disseminate the importance of space technology in the early stage. However, the activities of the Center were confined in limited users and narrow applications. The application of spatial technologies has gradually expanded to cover other areas of environmental management. More noteworthy development in this regard has been initiated by United Nation's Environmental Programme (UNEP) at the venue of ICIMOD during first half of 1990s when systematic efforts were launched to create digital database with diverse thematic orientations (Poudel 2005). ICIMOD established the Mountain Environmental Resources Information Systems - MENRIS within its structure with well strong Geographical Information Systems (GIS) and Remote Sensing (RS) capabilities in 1989 (ICIMOD 2006).

GIS is becoming a cross-cutting technology for the sustainable development of the mountain region. Since the establishment of MENRIS, priority has constantly been accorded on GIS and remote sensing based capacity building and networking, database management, and thematic applications. It has also been continuing partnerships with key software vendors of spatial data analysis technologies like ESRI, ERDAS and IDRISI. By the initiation of the support of the MENRIS on hardware, software and technical human resources National Planning Commission, Tribhuvan University and many other governmental institutions started to work on GIS platform since early 1990s. In the meantime UNDP and other international organizations also started to give support to capacity building, database preparation and application studies of various purposes and interests. Nepal GIS Society is also working for dissemination, networking and awareness creation through training, seminars, workshop and exhibition frequently. Because of these activities GIS and Remote sensing activities in the country are getting popularity at various level and capacity.

\section{RESEARCH ISSUES IN THE MOUNTAINS}

Mountains are the most prominent features of the landscape on the earth surface covering 15 to 20 percent of land area (Ives 1989:289) and exist in almost all continents. These are the homeland of about 10 percent of total human population (Grötzbach and Stadel 1997:17) and provide livelihood for several millions more. Mountains are distributed all over the continents with different location, direction and extensions. Mountain geography is highly varied and complex. The physiographic characteristics of the mountains of all continents have some commonalities whereas the human and socio-economic dimensions, resources potentialities, intensity of natural disasters and development perspectives have large diversities and variations (Stone 1992). Many spatial complexities are visible and active on determining the surface, sub-surface and interior forces of landscape changes. Mountains are highly sensitive because of their geophysical and geological basement and are also highly fragile because of their outer surface morphometry like slope, elevation, aspect, coverage, and other human induced activities.

Several sudden and local scales to global and longterm events and threats are directly associated with the mountain environments. The United Nations Conference on Environment and Development (UNCED) held in Rio de Janeiro in 1992 had identified three major environmental issues facing the global community in the $21^{\text {st }}$ century namely climate change, biodiversity and desertification. The follow up World Summit held in Johannesburg South Africa in 2002 reviewed progress after the Rio Summit. The Summit has pointed out that over 600 million people living in the mountains and foothills are within the direct impact of the climate changes and retreat of mountain glaciers (United 
Nations University 2005:375). The Human Development Report (2006) clearly indicates that the rural and urban slum areas of the world are under the severe water crises and closely interconnected with poverty, poor health quality, vulnerability and powerlessness (UNDP 2006). The distribution of the area under severe water crises covers the mountain region of the world.

Nepal is located at the central part of the Himalayan mountain system. Out of 4000 kilometers long stretch of the Himalayan systems from Afghanistan to Myanmar and eastern part of China, Nepal has nearly one-thirds of its length. Within a narrow belt of some 200 meter average width of west to east elongated country has elevation ranges from slightly below 60 meter from the mean sea level to 8848 meters on its highest peak Mt. Everest (Sagarmatha) and several other peaks above the 8000 meters. Therefore the vertical difference of the country has great diversity. Owing to these physiographic characteristics the country is specifically termed as 'mountainous country' although nearly one-thirds of its area is confined in the low-land tarai belt. Over 25 million people with different economic activities, social systems, cultural groups, language, religion and economic status live in the country; however, their concentration is not uniform. Tarai has generally dense population besides the urban centers. Mountain belt has sparse population distribution living amidst of inaccessibility and difficulties. In several contexts the high land-low land interactive systems are visible even though the country is divided into three distinct ecological and physiographic regions.

\section{APPLICATION OF GIS IN THE RESEARCH ISSUES OF THE MOUNTAINS}

The authors of 'the state of the world's mountainsa global report' have clearly envisaged the situation in early 1992, the sustainable mountain development discourse has laid a three basic steps i.e. "be aware of, study and supports the many courageous efforts of the mountain inhabitants themselves to reverse the present trends; create more awareness on a worldwide scale concerning the formidable dangers looming over the mountains and build up relevant, effective mountain constituency on all continents; and build up an cooperative network of national, regional and international institutions dealing with the issues of sustainable mountain development" (Stone 1992:9-10). This is an instance of the scientific concerns about the sustainable mountain development which has been a hot topic of discourse for a long time. The chapter 13 of the Agenda 21 of UNCED 1992 emphasized upon raising public awareness and ensuring adequate political, institutional, financial commitments for concrete action towards implementation of sustainable development.

The scientific communities strongly pleaded the quality of database for the prediction of the factual result, better scientific explanation based on the geospatial data, creating good archives for networking and sharing among the concerned stakeholders, implementers and scientific communities. One of the major challenges of mountain related problems in the region has got to do with limited availability and accessibility of geo-information and affordable tools and methods. Because of that, in the later days, major focus has been given to the collection of accurate geospatial information, their proper documentation, analysis and scientific interpretation.

United Nations Organizations are playing a decisive role on networking the importance of geospatial data infrastructure in the global arena. In 1994 the US President Bill Clinton first publicly emphasized the importance of geospatial data as “... to promote economic development, improve our stewardship of natural resources, and to protect the environment." (US President Clinton, 1994 cited in UNGIWG 2007) and then after the UN Geographic Information Strategic Plan (UNGISP) in 2001-2002 has highlighted its role in a wider scale (UNGIWG 2007).

Report of the Inter-Agency Meeting on Outer Space Activities on its twenty-fourth session (Geneva, 2123 January 2004) has reported United Nations General Assembly meeting that UNEP had continued its participation in the Sponsors' Group for the Global Observing Systems, helping to promote the Global Climate Observing System, the Global Ocean Observing System, the Global Terrestrial Observing System and the combined Global Observing Systems strategy, as well as remaining active in the Committee on Earth Observation Satellites. Similarly the report has mentioned the UNOSAT had been used by United Nations entities to respond to inter-agency mapping needs in Afghanistan (United Nations Environment Programme (UNEP)), Benin (UNEP/ United Nations Development Programme (UNDP)), Iraq (for humanitarian planning maps), Nepal (UNEP), Nicaragua (UNITAR) and the West Bank Office for the Coordination of Humanitarian Affairs (United Nations General Assembly 2004). The United Nations charters have clearly 
emphasizing the mandate of the application of global geospatial data infrastructure and earth observation satellite for humanitarian, poverty, environmental and disaster application in a wider scale. UNEP, UNESCO, FAO, WFP like several UN organizations are closely working with GIS and remote sensing technology based geospatial database application in their respective regular work and field programme.

Physiographic heterogeneity, verticality and variation of the mountain terrain, climatic variability and variation and social diversities are the major characteristics of the mountains. Mountain environment involves special consideration in the use of GIS. Three-dimensional mapping and virtual modeling from the topographic data, global positioning systems, satellite imageries and aerial photographs can be used. Environmental monitoring, climate change mapping, local and regional level planning, land use cover mapping and change monitoring, disaster and hazard mapping, suitability assessment, natural resources mapping and so on are the major applications of GIS. The applications are specifically based on the nature of the organization and the work mandate. In the present context of 'construction of new Nepal' GIS can be used on identification of federal units, poverty mapping and identification of planning gaps too. To these points GI Sciences can be applied in various purposes and aspects.

\section{SUGGESTIONS FOR NEW STRATEGIES}

Mountains have high degree of heterogeneities and complexities. Amidst of these contextual settings the geographic information and earth observation systems in mountainous regions generally present considerable challenges. Heywood et al. (1994) observe a common set of issues to apply GIS to management and research in the mountain context are data, organizational and theoretical. GIS is a 'post industrial technology' developed for the needs of North America and Europe and to apply this technology in the developing countries generally have considerable challenges (Heinimann et al. 2003). Specifically, those issues of GIS activities in the developing countries have been observed as organizational level that is to alter power relations in governmental structure, adequate funding and staffing over a reasonable period of time, empowering of local technical staff through the transfer of know-how and by continued backstopping based on a long term commitment. Data issues concerns with the availability, sharing and exchange by solving pertaining legal matters.
Mountains have specific geographical settings pose technical level and practical interaction and exchange among the experts and stakeholders. Great spatial heterogeneity requires refined technical approaches and accurate input of information.

For the sake of effective application of GIS in the mountain environment some new strategies are suggested, which are as follows:

Capacity building and knowledge management of the human resources of the government and institutions in the country are the first need. Mountain has large diversity on its geographical characteristics, without understanding those characteristics and the proper handling of hardware and software that make a big problem on implementation of GIS. On the other hand country has not well equipped academic institution for the GIS so far. Therefore, establishment of a national level GIS Center with adequate infrastructural capacity is mandatory. University has to take initiation to establish and develop.

Database is a big issue of the object-oriented research and development planning, however, the existing status of the spatial database infrastructure is not satisfactory. Different organizations have different sources and style of database collection, preparation and management. Very poor database sharing and networking often creates work duplication and unnecessary budgetary investment. It is said that GIS-based project requires around 70 percent of its cost involvement during the data collection and preparation phase and only around 30 percent for the remaining jobs. Therefore, strategy has to be developed for the database sharing and networking among the institutions working with the GIS. For the effective database sharing and networking a national level governing body has to be constituted from the representation of the technical team of public and private institutions. The body has to be authorized the legal and technical issues and policy design for the 'National Spatial Data Infrastructure' (N-SDI). Within the guidelines of the NSDI all the sectoral ministries and departments of the government and the private institutions working on GIS have to bring under the compulsion to follow actions. National Planning Commission Secretariat (NPCS) and High Level Commission for Information Technology (HLCIT) have to take initial initiation.

Existing working methods and mentality have to upgrade by individual, organizational and instructional level with a view to changing global context along with the development of ICT and the 
'digital data revolution'. So far country has poor institutional linkages, weak technical competencies, lack of adequate funding and staffing, passiveness on commitment of the government to work on objective output of the investment made in the annual and periodic budget outflow, paper work and invoice based monitoring practices are some of the decisive drawbacks of the effective implementation of GIS and technology in the country. Because GIS pleads the facts with the objectbased spatial database in which the conventional tendency of working style does not match. Therefore, the monitoring and evaluation of the budget flow and progress has to be made based on the object-oriented spatial information.

\section{REFERENCES}

Aronoff, S. 1989. Geographic Information System: A Management Perspective. Ottawa: WDL Publishers

Bell, J. 1999. Doing Your Research Project: a guide for first-time researchers in education and social science ( $3^{\text {rd }}$ edition). New Delhi, Viva Books Private Limited

Deichmann, U. and Wood, S. 2005. GIS, GPS and Remote Sensing. GIS Nepal. Vol. IV.6-8 (adapted from http://www.ifpri.org/)

Goodchild, Michael F. 2004. GIScience, geography, form, and process. Annals of the Association of Amirican Geographers. 94(4):709-714

Grötzbach, E. and Christoph, S. 1997. Mountain people and culture. In B. Messerli and J.D. Ives (ed.) Mountains of the World: A global Priority. New York and London: The Parthenon Publishing Group. Pp. 17-38

Heinimann, Andreas, Breu, Thomas, Kohlor, Thomas 2003. The challenges of applying geographic information systems to sustainable mountain development. Mountain Research and Development, vol. 23 (4):312-319

Heywood, D. Ian, Price, Martin F. and Petch, James R. 1994. Mountain regions and geographic information systems: an overview. In Martin F. Price and D. Ian Heywood (ed.) Mountain Environments and Geographic Information Systems. London: Taylor and Francis, Pp. 1-24

Howard, K. and Sharp J.A. 1983. The Management of Student Research Project. Aldershot: Gower.

ICIMOD 2006. ICIMOD: Achievements, Challenges, and Lessons Learned. Kathmandu, International Center for Integrated Mountain Development
Ives, J. D. 1989. Mountain environments. In G. B. Martini-Bettolo (ed) Study Week On: A Modern approach to the Protection of the Environment. November 2-7, 1987. New York: Pergamon Press

Peuquet, Donna J. and Marble, Duene F. 1990. What is a Geographic Information System? In Donna J. Peuquet and Marble F. Duane (eds.) Introductory Reading in GISs. New York. Taylor and Francis

Poudel, K. 2005. GIS and remote sensing in Nepal: surviving amidst chaos. GISNepal, Vol. IV. Pp. 10-12

Stone, Peter B. (ed.) 1992. The State of the World's Mountains: A Global Report. London and New York: Zed Books Ltd

UNDP 2006. Human Development Report 2006: Beyond scarcity: Power, poverty and the global water crisis. New York: United Nations Development Programme

UNGA 2004. Report of the Inter-Agency Meeting on Outer Space Activities on its twenty-fourth session, Committee on the Peaceful Uses of Outer Space (Geneva, 21-23 January 2004), United Nations General Assembly. A/ AC.105/818

United Nations Geospatial Infrastructure Working Group UNGIWG 2007. Strategy for developing and implementing a United Nations Spatial Data Infrastructure in support of Humanitarian Response Economic Development Environmental Protection Peace and Safety. United Nations www.ungiwg.org/docs / unsdi/UNSDI_Strategy_Implementation_Paper.pdf (visited 23 November 2007)

UNU 2005. Climate change initiative, sustainable land management in Central Asia. (Mountain Notes). In Mountain Research and Development, Vol. 25 (4). pp372-375 